\title{
Public Reason and Political Conflict:
}

\section{Abortion and Homosexuality}

\author{
Robert P. George ${ }^{\dagger}$
}

Is it possible for people who sharply disagree about important questions of morality, including those pertaining to abortion and homosexuality, to constitute a stable political society whose basic constitutional principles can be affirmed as just by all reasonable parties? This question is not about the possibility of political compromise; rather, it concerns the possibility of a certain type of moral agreement. This type of moral agreement is not agreement about whether abortion or homosexual conduct, for example, are right or wrong. Instead, it is agreement about basic principles of justice for a society composed of people who disagree about such issues.

One possibility is for people who disagree about the morality of particular acts or practices to agree upon fair procedures for the political resolution of moral disagreements. For example, people who disagree about the morality of abortion might, as a constitutional matter, agree upon democratic procedures for setting public policy on abortion. However, people of strong and settled conviction on either side of the debate over aborion cannot reasonably be satisfied of the justice of the fundamental law of their country simply because the procedures used to arrive at a resolution were democratic. From the pro-life point of view, any regime of law (including one whose pedigree is impeccably democratic) that deprives unborn human beings of their right to legal protection against homicide is gravely unjust.' Similarly, from the pro-choice viewpoint, restrictions on a woman's right to abortion are seriously unjust even if they were put in place by democratic procedures. From either perspective, the question of abortion is viewed as a matter of fundamental justice whose proper resolution is essential to the full moral legitimacy of the constitutional order. In this respect, the social conflict over abortion closely resembles the conflict over slavery. Of course, pro-life and pro-choice advocates may, for

i Associate Professor of Politics, Princeton University. Commissioner. United States Commisston on Civil Rights; Of Counsel, Robinson \& McElwce. Charleston. West Virginis The authur wishes to thank William C. Porth, John Finnis, and Gerard V Bradlcy for many helpful suggestuons. and the Earthart Foundation for its suppor.

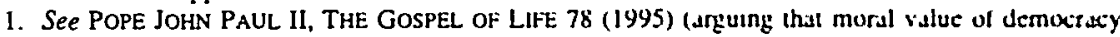
"is not automatic, but depends on conformity to the moral law to which il. hike every other turm ol human behavior, must be subject"). On the interpretation of the Pope's teaching. see Ruben P Geurge. The Tirant State, 67 FIRST THINGS 39 (1996). 
their own partisan reasons, or as part of a modus vivendi, agree to a constitutional requirement that public policy on abortion be settled by democratic procedures. But agreement of this sort is not agreement on basic principles of justice.

A number of leading liberal political theorists have proposed a different, and more radical, possibility. They contend that people who disagree about abortion, homosexuality, and other matters of allegedly "private" or "personal" morality can and should agree as a matter of fundamental justice to a constitutional principle that forbids government from substantially restricting or burdening people's liberty, or denying them equality of treatment, on the basis of controversial moral judgments about such matters. ${ }^{2}$ This principle is one version of what is sometimes referred to as "antiperfectionism." Its proponents seek to provide the ground of a moral right, for example, to legal abortion and the legal recognition of same-sex unions, a ground which can rationally be affirmed as a principle of political justice even by people who believe that abortion and homosexual conduct are seriously immoral.

Why should people agree to the antiperfectionist principle? After all, the question of whether abortion and homosexuality are purely "private" or "personal" matters-matters that implicate no significant public interests-is as much in dispute as the question of whether these acts are immoral. From the pro-life point of view, abortion is no more "private" than infanticide and other forms of homicide. From the perspective of those who object to the public recognition or promotion of same-sex sexual relationships, the issue is no more a matter of merely "personal" morality than was (and is) the issue of polygamy. Understandably, critics of antiperfectionism suspect that it represents a kind of philosophical sleight of hand designed to induce dissenters from substantive liberal moral beliefs to accede to liberal hegemony in matters of public policy pertaining to issues such as abortion and homosexuality. ${ }^{3}$

Are antiperfectionism's critics correct? Or can a sound argument in defense of antiperfectionism be developed? In this Essay, I shall consider the recent effort of John Rawls and some of his followers to defend antiperfectionist liberalism in the form of a doctrine of "political justice." Their criteria of legitimate political advocacy and action in societies marked by

2. See, e.g., BRUCE A. ACKERMAN, SOCIAL JUSTICE IN THE Liberal STATE 349-78 (1980); RonALD

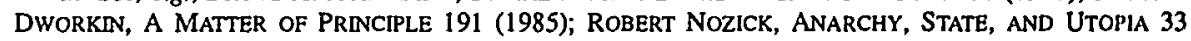
(1974); JOHN RAWLS, A THEORY OF JUSTICE 327 (1971).

3. See J.M. Finnis, Legal Enforcement of "Duties to Oneself": Kant v. Neo-Kantians, 87 CoLuM. L. Rev. 433 (1987); Alasdair McIntyre, The Privatization of Good, 52 REv. Pol. 344 (1990). See generally Robert P. GEORGE, MAKING MEN MORAL: CIVIL LIBERTIES AND PUBLIC MORALTTY 83-109, 129-60 (1993). Of course, not all defenders of liberalism or specific liberal positions embrace antiperfectionism. Joseph Raz, for example, is among antiperfectionism's most powerful critics. See JosEPH RAZ, THB MORALITY OF FREEDOM (1986); Joseph Raz, Facing Diversity: The Case of Epistemic Abstinence, 19 PHIL. \& PUB. AfF. 3 (1990); see also William A. Galston, Liberal PuRposes: Goods, VIRTUES, AND DINERSTYY IN THE LIBERAL STATE 79-162 (1991) (criticizing premise that liberalism should or can be "neutral"). 
group conflict over issues such as abortion and homosexuality centers around the idea of "public reason." I shall try to show that their arguments fail to provide compelling grounds for embracing antiperfectionism, and I shall illustrate this point by criticizing: (1) the sketch of a defense of a right to abortion proposed by Rawls in Political Liberalism and developed in greater detail by Judith Jarvis Thomson; and (2) Stephen Macedo's Rawlsian argument for the legal recognition of same-sex "marriages." I will then provide suggestions as to how people with such disagreements can discuss and debate their beliefs in a peaceful and civil manner.

\section{Political Liberalism and the Rationalist Believers}

\section{A. The Rawlsian Conception}

In his profoundly influential book, $A$ Theory of Justice, Rawls defended a strict antiperfectionism. ${ }^{4}$ This defense was embedded in a general theory of justice ("justice as fairness") that Rawls now says relied on a premise which the theory itself rules out, namely, the idea that "in the well-ordered society of justice as fairness, citizens hold the same comprehensive doctrine, and this includes aspects of Kant's comprehensive liberalism, to which the principles of justice as faimess might belong." The problem with this idea is that neither liberalism, considered as a "comprehensive doctrine," nor any other comprehensive view is held by citizens generally in pluralistic societies such as ours. Nor is it reasonable under the circumstances of political freedom that characterize modern constitutional democratic regimes to expect that "comprehensive liberalism," or any competing comprehensive view, ever would be adopted by citizens generally. Rawls refers to this state of affairs as

4. See RAWLS, supra note 2, at 327-30.

5. John Rawls, Polmical Liberalism at xli (2d ad. 1996) For a powerful crithque of this work (including a valuable summary of criticisms and defenses of Rawls advaneed by ohers). see Heidi $M$ Hurd, The Levitation of Liberalism, 105 YALE L.J. 795 (1995) (book revew) My own crituque or Rawls in the pages that follow is concemed with different problems than those idenufied by Professor Hurd In particular, I aim to show that Rawls fails to justify his claim that certain pnnciples. despute the fact that they are (or may be) true principles of justice (or polsucal morality more generally), are not legitumale grounds of political advocacy and action in pluralisuc socicties such as ours because they are drawn from "general" or "comprehensive" doctrines which are in dispute among reasonable people I challenge Rawls's "political liberalism" insofar as it treats such principles, at least when it comes to debales about "constitutional essentials and mauters of basic justice." as being outside the bounds of "public reason " Readers familiar with discussions of Rawls's thought will notuce that my concerns are. at most. only indirectly related to "communitarian" criticisms of Rawls which claım that his liberal individualusm reflects an inadequate regard for community values and the value of community. My goal is to cast doubr upon the philosophical tenability of Rawls's antiperfoctiontsm. Thus, my crituue has points in common with critiques of Rawls by Miriam Galston, Rassion Dualism and the Autonomy of Poltucal Thought. 94 COLUM. L. REV. 1842 (1994); Lawrence E. Mitchell. Trust and the Overlapping Consensus. 94 Colus! L. REV. 1918 (1994); Michael P. Zucken, The New Rawls and Constnumonal Theon: Does It Really Taste That Much Better?, 11 CONST. COMMeNTARY 227 (1994); and Michael J. Sandel. Polincal Liberalusm. 107 HARV. L. REV. 1765 (1994) (book review). 
"the fact of reasonable pluralism," and it is the starting point of his revised argument for an antiperfectionist resolution of the problem of moral disagreement. $^{6}$

Rawls labels his revised proposal "political liberalism." His idea (or ideal) is that, for constitutional democratic societies such as ours,

citizens are to conduct their public political discussions of constitutional essentials and matters of basic justice within the framework of what each sincerely regards as a reasonable political conception of justice, a conception that expresses political values that others as free and equal also might reasonably be expected reasonably to endorse. ${ }^{7}$

In this framework, "deeply opposed though reasonable comprehensive doctrines may live together and all affirm the political conception of a constitutional regime." ${ }^{8}$ Debates over constitutional essentials and matters of basic justice are, for moral reasons (and not as a mere modus vivendi), to be conducted in terms of a "strictly political conception of justice," such as "justice as faimess"10 as revised by Rawls in Political Liberalism. These debates are not to be conducted in terms of moral doctrines of justice, whether secular (e.g., Kantian or Millian liberalism) or religious (e.g., Catholic or Jewish), which are "general in scope"11 and in dispute among reasonable citizens. In sharing a common "political" conception of justice, the partisans of competing reasonable comprehensive doctrines participate in an "overlapping consensus" on basic principles of justice, ${ }^{12}$ thus making social stability (despite the fact of pervasive moral disagreement about personal and social life) not only possible, but also possible "for the right reasons."13

The alternative to a common commitment to a "political" conception of justice is for citizens in pluralistic societies to debate issues of constitutional essentials and matters of basic justice by appealing to general moral doctrines of justice connected to their various reasonable comprehensive views. In that case, liberalism-representing one comprehensive view with its own reasonable, but controversial, moral and metaphysical doctrines-would compete for ascendancy in the public square with a range of alternative religious and secular comprehensive views, some reasonable, some not, ${ }^{14}$ but

6. See RAWLS, supra note 5 .

7. Id. at 1 (citation omitted).

8. Id. at $\mathrm{xx}$.

9. Id. at xvii.

10. Id.

11. Id.

12. Rawls explains that "in an ideal overlapping consensus, each citizen affirms both a comprehensive doctrine and the focal political conception, somehow related." Id. at xxi.

13. Id. at xlii, $390,392$.

14. Rawls says that political liberalism "supposes that a reasonable comprehensive doctrine does not reject the essentials of a democratic regime." Id. at xviii. 
all characterized by controversial moral and metaphysical doctrines of their own. Rawls argues against this alternative, not on pragmatic grounds (such as fear that the conflict of comprehensive views at this level could lead to civil strife), but on moral grounds. ${ }^{15}$ A strictly "political" conception of justice is, he maintains, the fairest and most reasonable way of settling constitutional essentials and matters of basic justice. "Political," as opposed to "comprehensive" or "metaphysical," liberalism consists precisely in the adoption of such a conception.

What this means concretely is that, whenever constitutional essentials and matters of basic justice are at stake, political actors-including citizens as voters and public political advocates-are forbidden to act on the basis of principles drawn from their comprehensive doctrines, except to the extent that "public reasons, given by a reasonable political conception, are presented sufficient to support whatever the comprehensive doctrines are introduced to support." "In this way, political liberalism constrains-sometimes quite radically-appeals to, and actions based upon, comprehensive doctrines including comprehensive liberalism. It does so on grounds entirely separate from the putative falsity, unsoundness, or unreasonableness of those doctrines or the specific principles drawn from them. Appeals to comprehensive doctrines are never legitimate in legislative assemblies or in the public acts and pronouncements of executive officers. ${ }^{17}$ Nor, above all, may judges in a constitutional democracy with judicial review justify their decisions by appealing to principles drawn from comprehensive doctrines. ${ }^{18}$

Undoubtedly having in mind criticisms of $A$ Theory of Justice advanced by Alasdair MacIntyre, Michael Sandel, Charles Taylor, and others, ${ }^{19}$ Rawls insists that "[p]olitical liberalism is not a form of Enlightenment liberalism, that is, a comprehensive liberal and often secular doctrine founded on reason and viewed as suitable for the modern age now that the religious authority of Christian ages is said to be no longer dominant." ${ }^{.20}$ It is, rather,

a political conception of political justice for a constitutional democratic regime that a plurality of reasonable doctrines, both religious and nonreligious, liberal and nonliberal, may freely endorse, and so freely live by and come to understand its virtues. Emphatically.

15. See id. at $173-212$.

16. Id. at li. Rawls refers to this as "the wide view" of public reason Id at hit He introduces it in the Introduction to the paperback edition of Political Luberalism as a revision of the somewhat mure restnctuve view (though referred to as "the inclusive view" inasmuch as $₫$ was less restnctuve than "the exclusive view" of public reason to which he was originally inclined) set forth later in the (ext See id at 247-52

17. See id. at 215-16.

18. See id. at 216.

19. See generally ALASDAIR MACINTYRE. AFTER VIRTUE A STUDY IN MORAL THEORY 246-52 (2d ed. 1984); MICHAEL J. SANDEL, LIBERALISM AND THE LIMTSS OF JUSTICE 28-16 (1982). CHARLIS TAYLOR, SOURCES OF THE SELF: THE MAKING OF THE MODERN IDENTTTY 88-89 (1989)

20. RAWLS, supra note 5, at Xl. 
it does not aim to replace comprehensive doctrines, religious or nonreligious, but intends to be equally distinct from both and, it hopes, acceptable to both. ${ }^{21}$

"Political liberalism" claims to be "impartial" between the viewpoints represented by the range of competing reasonable comprehensive doctrines, be they liberal or nonliberal, secular or religious. ${ }^{22}$ Indeed, according to Rawls, "political liberalism does not attack or criticize any reasonable view." says that "rather than confronting religious and nonliberal doctrines with a comprehensive liberal philosophical doctrine, the thought is to formulate a liberal political conception that those nonliberal doctrines might be able to endorse."24

If Rawls is correct, not only people who subscribe to one or another comprehensive form of liberalism, but also traditional Catholics, evangelical Protestants, and orthodox Jews-assuming their viewpoints are reasonable (something Rawls seems to suggest he is willing to assume)-ought to be able reasonably to embrace a purely "political" liberalism while in no way compromising their fundamental moral and religious beliefs and commitments. Precisely to the extent that they are reasonable, various comprehensive views, including religious ones, can be part of the overlapping consensus of political liberalism which ensures social stability. ${ }^{25}$

Although he observes that a de facto modus vivendi might, in particular circumstances, develop into an overlapping consensus, ${ }^{26}$ Rawls emphatically denies that the overlapping consensus constitutes, or necessarily results from, a mere modus vivendi. ${ }^{27}$ The key is that the overlapping consensus is characterized by a certain type of reasonable moral agreement about what, at a basic level defined by principles and ideals, constitute fair terms of social cooperation among people who, being reasonable, view each other as free and equal citizens. Thus, "political liberalism," though representing a "freestanding" conception of justice, ${ }^{28}$ is a moral conception, containing "its own intrinsic normative and moral ideal." 29

Terms of cooperation offered by citizens to their fellow citizens are fair, according to Rawls, only to the extent that "citizens offering them ...

21. Id.

22. See id. at $\mathrm{xxi}$.

23. Id. By way of criticism, it is worth remarking here that "political liberalism" imposes a heavy burden on comprehensive doctrines by delegitimizing the expression of certain views in the field of political advocacy and relegating their significance to the purely private realm.

24. Id. at xivii.

25. See id. at xlii.

26. See id. at $158-68$.

27. See id. at $146-48$.

28. A "freestanding" conception is one that is not presented as in any sense derived from or a part of a comprehensive doctrine. See id. at 10.

29. Id. at xliv. 
reasonably think that those citizens to whom such terms are offered might also reasonably accept them." ${ }^{130}$ Rawls refers to this requirement as "the criterion of reciprocity."31 It is the core of what Rawls calls "the liberal principle of legitimacy," namely, that "our exercise of political power is fully proper only when it is exercised in accordance with a constitution the essentials of which all citizens as free and equal may reasonably be expected to endorse in the light of principles and ideals acceptable to their common human reason." ${ }^{32}$ Only when political power is thus exercised do political actors (including voters) act consistently with the ideal of "public reason." ${ }^{33}$

\section{B. The "Rationalist Believers"}

A central point and effect of the liberal principle of legitimacy and the ideal of public reason is to exclude as illegitimate, in the framing of a constitution and in legislative and judicial deliberations touching upon constitutional essentials or basic matters of justice, ${ }^{34}$ certain principles and other propositions even though they are, or may well be, true. It is easy enough to see how such an exclusion might, in certain circumstances, be reasonable, prudent, and thus warranted as part of a modus vivendi. ${ }^{35}$ It is far from obvious, however, that people are obligated morally, in circumstances in which they are not obliged as a matter of political prudence, to refrain from acting on principles that they reasonably believe to be true and that are not

30. Id. As discussed below, this concepuon of the fauness of tems of coupcration. interpreted narrowly, is neither controversial nor original. Rawls, however, interprets it broadly so as to delegutumize any independent appeal, in the political arena, to a "comprehensive vew" of justuce and the common good. It is difficult to see how someone could reasonably embrace this position and thereby rule out public advocacy based on the most deeply held attachments of one's fellow citizens it is far from obvious that reason obliges anyone to sacrifice such attachments or to stay stlent about them. and it is stnkingly unreasonable to think that people would willingly forbear such witness. Moreover, it is cunous that Rawls's principle seems to be anything but evenhanded in effect (as between the policy preferences of. say. secular liberals and traditional religious believers), and there can $b e$ no doubt that some persons embrace unth a content-partial desire to foreclose specific advocacy from specific quarters Cf Paul F Campos. Secular Fundamentalism, 94 CoLUM. L. REV. 1814, 1825 (1994) ("Polutical Liberalism is ulumately a paean to a secular creed that has within it the potential to become every bit as monstuc, compulsory. and intolerant of any significant deviation from social venties as the tradituonal modes of belief it dended and displaced."); Gary C. Leedes, Rawls's Excessively Secular Polirical Concepnon. 27 U RICH L. REV 1083. 1086 (1993) (arguing that Rawls's principle is usod to exclude religious viewpoints)

31. RAWLS, supra note 5, at xliv.

32. Id. at 137. According to Rawls, "politucal nghts and dutues are moral nghts and dutses, for they are part of a political conception that is a normative (moral) conception with its own intrinsic tdeal, though not itself a comprehensive doctrine." Id. al xlıv.

33. See id. at 137 ("Only a political conception of justuce that all ciuzens might be reasonably expected to endorse can serve as a basis of public reason and jusufication.")

34. See id.

35. Depending on circumstances, one might, therefore, affirm what Judith Shklar called the liberal ism of fear." See JUDITH N. SHKLAR, ORDINARY VICES 192-226 (1984) John Rawls has noted that Shklar's idea that the "liberalism of fear," or the form of liberalism represented by thukers such as Montaigne and Montesquieu, finds its historical origins in a pragmatic response to the cruclues of the Reformation and its aftermath. See RAWLS, supra note 5, at xxvi \& n.10. 
ruled out as reasons for political action by their reasonable comprehensive doctrines of justice and political morality.

Of course, a particular comprehensive view might identify reasons, even reasons of principle and not mere prudence, for declining to enforce by law or otherwise to take political action based on certain types of moral obligations. Certain comprehensive liberalisms, such as the liberalisms of John Stuart $\mathrm{Mill}^{36}$ and Joseph Raz, ${ }^{37}$ purport to identify such principles. It is, of course, crucial to Rawls's project to avoid an appeal to any such comprehensive liberalism. His claim is that the rational moral force of the liberal principle of legitimacy and of the ideal of public reason depends in no way on the truth of comprehensive liberalism in any form.

When citizens disagree with one another about certain basic moral, political, and religious questions, what does it mean for them to propose terms of social cooperation that they reasonably think their fellow citizens can reasonably accept? If the criterion of reciprocity and the principle of legitimacy are interpreted narrowly, it simply requires that those citizens proposing terms of social cooperation must reasonably think that they are giving their fellow citizens who disagree with them about particular fundamental matters sound reasons, accessible to them as rational persons, for changing their minds. Under such a narrow interpretation, the scope of public reason would be correspondingly wide. Although it would exclude appeals to sheer authority, or "secret knowledge," or to putative truths revealed only to an elect few and not accessible to reasonable persons as such, it would not rule out in advance of argument on the merits any principle or proposition, however controversial, which is (or can be) defended by rational argument. ${ }^{38}$

Of course, this interpretation (and the very wide view of public reason it would authorize) is not one Rawls can accept, for it does not limit the field of acceptable doctrines of political morality to political liberalism. It will not serve to exclude ideals and principles drawn from comprehensive forms of liberalism, for example. More to the point, it will not rule out certain notable nonliberal comprehensive views which similarly appeal to our "common human reason." The broad tradition of natural law thinking, for example, proposes what amounts to its own principle of public reason when it asserts that questions of fundamental law and basic matters of justice ought to be decided in accordance with natural law, natural right, natural rights, and/or natural justice. ${ }^{39}$ If Rawls is to sustain his bold claim that "[o]nly a political

36. See JOHN STUART MILL, ON LIBERTY 44-57 (Longmans, Green, Reader \& Dyer 1873) (1859) (stating that principle of libery forbids others from interfering with individual's purcly "self-regarding" conduct, even on ostensibly moral grounds).

37. See Joseph Raz, Liberty and Trust, in NATURAL LAW, LibERALISM, AND MORALITY 122-26 (Robert P. George ed., 1996).

38. See infra Part IV.

39. In Aquinas's natural law theory, something is good, right, or just "by nature" insofar as it is reasonable. See Thomas AQUNAS, Summa THeOlogiaE I-II, Q. 71, art. 2, translated in JoHN FinNIS, 
conception of justice that all citizens might reasonably be expected to endorse can serve as a basis of public reason and justification, ${ }^{n 0}$ he must defend a broad version of the legitimacy principle, one that restricts the scope of public reason sufficiently to exclude not only comprehensive doctrines that appeal to secret knowledge or private revelation, but also comprehensive doctrines that appeal to publicly accessible reasons. Relatedly, he must show that the putatively strictly "political" conception of justice can guarantee the liberal conclusions he favors on questions that from the liberal point of view touch upon constitutional essentials and matters of basic justice, without smuggling into the justification for these conclusions disputed principles or propositions drawn from a comprehensive liberalism.

In Political Liberalism, Rawls considers the case of "rationalist believers who contend that [their] beliefs are open to and can be fully established by reason." 41 Oddly, he says that this contention is "uncommon," when it is, in fact, the claim of what Sir Isaiah Berlin, whose own sympathies are plainly liberal, has called "a central strand in the whole tradition of western thought." ${ }^{43}$ In any event, Rawls's remarkably brief argument against the socalled rationalist believers is based entirely on the claim that they unreasonably deny "the fact of reasonable pluralism." Rawls means by "rationalist believers," then I am something of one myself. I certainly do not deny that people in our culture, including reasonable people, disagree about fundamental moral questions, such as the morality of abortion and homosexual acts. Nor need people like me deny that some measure of moral disagreement is in some sense inevitable under circumstances of political and religious freedom. In precisely what sense, then, do we, according to Rawls, deny the fact of reasonable pluralism?

To be faithful to his own methodological scruples, Rawls must avoid denying the truth of the reasonable, albeit controversial, moral, metaphysical, and religious claims that he wishes to exclude as reasons for political action under the principle of legitimacy. He must, therefore, adduce grounds other than their falsity for their exclusion. If he is reduced to arguing on the merits for the falsity of these claims, the case for "political liberalism" has been fatally compromised. Rawls's strategy is not to deny the truth of the claims of

NATURAL LAW AND NATURAL Rights 36 (1980) (hereinafter FinN1s. NATURAL LAW] (The good of the human being is being in accord with reason, and human evil is being outside the onder of reasonubleness ") Finnis has explained that "for Aquinas, the way to discover what is morally nght (vinue) and wrong (vice) is to ask, not what is in accordance with human nature, but what is reasonable " FINits. NATURAL LAW, supra, at 36; see also JOHN FINNIS. AQUNAS: MORAL LtGAL, AND POLTICAL. THEOKY (forthioming 1998).

40. RAWLS, supra note 5, at 137 (emphasis added)

41. Id. at 152-53.

42. Id. at 153 .

43. ISAIAH BERLIN, THE CROOKED TIMBER OF HUMANITY Chafters IN thit HLSTORY Of IDEAS 24 (1991).

44. RAWLS, supra note 5, at 153. 
rationalist believers, but merely to deny that their claims "can be publicly and fully established by reason." ${ }^{.45}$ This denial can be sustained, however, only by addressing the merits of the actual arguments that the rationalist believers publicly advance in support of their beliefs, arguments which the liberal principle of legitimacy and the Rawlsian ideal of public reason are meant to rule out in advance, irrespective of their soundness, on grounds independent of the truth or falsity of the principles the arguments are meant to vindicate.

Rawls's insistence that he is not denying the truth of rationalist believers' beliefs, but only their assertion that these beliefs can be publicly and fully established by reason, is therefore unavailing. Rationalist believers do not claim on the basis of secret knowledge or special revelation that their beliefs are publicly justifiable by rational argument; on the contrary, they defend their views precisely by offering public justification, that is, rational arguments in support of the principles and propositions on the basis of which they propose political action. ${ }^{46}$ These arguments are either sound or unsound. If sound, there is no reason to exclude the principles and propositions they vindicate as "illegitimate" reasons for political action. If unsound, they should be rejected-on rationalist believers' own terms-precisely for that reason.

Consider the matter from the viewpoint of people to whom the arguments of rationalist believers are addressed. Those who, upon reflection, are persuaded by arguments that appeal to their "common human reason" obviously have no ground for excluding as in principle "illegitimate" or "contrary to public reason" these principles and propositions as reasons for political action. People who are not persuaded will consider that the arguments advanced for these principles and policies are unsound or, in any event, insufficient to warrant belief in, and action based on, the principles and propositions in support of which they are advanced. They will, of course, consider those who are persuaded to be in error (and vice versa), but they have no grounds for supposing them to be acting in violation of a principle of legitimacy by preparing to exercise public power, or to support the exercise of such power, for "nonpublic" reasons.

Do rationalist believers deny the possibility of reasonable disagreement? Rawls says that, "[i]t is unrealistic-or worse, it arouses mutual suspicion and hostility-to suppose that all our differences are rooted in ignorance and perversity, or else in the rivalries for power, status, or economic gain." ${ }^{\text {47 }}$ True, but rationalist believers recognize that many differences, including

45. Id.

46. See, e.g., HADLEY ARKEs, FIRST ThINGS: AN INQUIRY INTO THE FIRST PRINCIPLES OF MokALS AND JUSTICE (1986); FINNIS, NATURAL LAW, supra note 39; JOHN FINNIS ET AL., NUCLEAR DETERRENCE, MORAlitY, AND REalism (1987); GERMAIN G. GRISEZ, ABORTION: THE MYTHS, THE REALITIES, AND THE ARGUMENTS (1970); Robert P. George \& Gerard V. Bradiey, Marriage and the Liberal Imagination, 84 GEO. L.J. 301 (1995).

47. RAWLS, supra note 5 , at 58. 
certain political differences, arise from considerations that are underdetermined by reason such as matters of taste or sentiment, or from reasonably guided, albeit still rationally underdetermined, prior commitments and the distinctive perspectives and responsibilities flowing from them, or from the diversity of reasonable beliefs about the likely consequences of alternative possible courses of action. There may be in such cases a variety of unreasonable opinions; but there need not be a uniquely reasonable or correct one.

In other matters, however, including fundamental political matters such as questions of human rights, there are uniquely morally correct beliefs that are, in principle, available to every rational person, or so rationalist believers hold. Differences with regard to such matters may be "reasonable," in the sense that reasonable persons can err about such matters (which may be complicated and difficult), and, indeed, can sometimes err without subjective moral fault. Still, some error of reason must be responsible for anyone's failure to arrive at a correct opinion with regard to such matters. Errors may be rooted in inattention to or ignorance of certain facts or values, subrational influences that block insight but may be subjectively nonculpable, logical failure, or other mistakes in judgment that can be induced or at least facilitated by particular cultures. ${ }^{+3}$

Is this view unreasonable? Rawls speaks of competing comprehensive views that are "perfectly reasonable" 49 and of persons subscribing to different views who are nonetheless "fully reasonable." Uno Uness he is to violate his own methodological scruples by appealing to some form of moral relativism, Rawls cannot declare the view of rationalist believers to be unreasonable because they hold that conflicting views on moral questions, including some questions of human rights, on which "reasonable people disagree" cannot be equally reasonable. There is nothing unreasonable in holding that the view of those in error is less than fully or perfectly reasonable, and that they, to the extent that their view deviates from the correct one, are (perhaps nonculpably) being less reasonable than their opponents who have managed to get to the truth of the matter at issue.

Indeed, it is difficult to see how Rawls himself could defend a contrary position. After all, there are reasonable people who reject "political liberalism." Rawls must suppose that they are in error. Persons who consider other people to be in error can, of course, do so compatibly with a recognition of their own fallibility. Nevertheless, to the extent that their view deviates from the correct one--perhaps because they misunderstand or fail to appreciate the force of one or more of Rawls's central arguments-Rawls must suppose that they are being less reasonable than those who grasp his arguments, appreciate their

48. See Robert P. George, Law, Democracy, and Moral Disagreement, 110 HARV L REV 1388 (forthcoming May 1997).

49. RAWLS, supra note 5, at 24 n.27.

50. Id. at 58 . 
force, and therefore affirm the superiority of "political liberalism" to its alternatives.

Must rationalist believers reject Rawls's account of the sources of reasonable disagreement in connection with what he calls "the burdens of judgment"? ? $^{51}$ That account is not without its ambiguities. If, however, it is read in such a way as to avoid its collapse into relativism, then Rawls's idea of "fully reasonable," or even "perfectly reasonable," though erroneous, views refers to false beliefs that are formed by people without subjective fault. This is what people generally have in mind when, although themselves persuaded of the truth of a certain view, they nevertheless allow that the relevant subject matter is one about which "reasonable people can disagree." The possibility of reasonable disagreement in this sense is, however, no reason to exclude public argument as to the truth of the matters in question. John Finnis's remark on this point strikes me as entirely apt: "Public reasoning should be directed to overcoming the relevant mistakes, not pre-emptively surrendering to them." 52

In $A$ Theory of Justice, Rawls defended his substantive principles of justice by way of a "political constructivism" that asked what principles reasonable parties in an original position, behind a "thick" veil of ignorance, and thus possessed of merely a "thin" theory of the good, would choose for a society in which they would eventually occupy a place. ${ }^{53}$ In Political Liberalism, he indicates that the principle of legitimacy and the limits or guidelines of public reason "have the same basis as the substantive principles of justice." 54 This is shaky, for neither Rawls nor his followers have ever provided any reason to believe that perfectionist principles that would not be chosen under conditions of artificial ignorance by the unnaturally risk-averse parties in the original position are unjust, or are not valid principles of justice. The key point is this: From the proposition that principles that would be chosen by such parties under such conditions are just (and are principles of justice), it simply does not follow that perfectionist principles that might very well be chosen by reasonable and reasonably well-informed persons outside the Rawlsian original position are unjust (or are not principles of justice).

\section{ABORTION AND PUBlic REASON}

Although his desire to defend "political liberalism" requires Rawls to resist the very wide view of public reason that could be endorsed by natural law theorists or other so-called rationalist believers, he is nevertheless eager to

51. See id. at 54-57.

52. John Finnis, Rawls and Political Liberalism 8 (Feb. 24, 1996) (unpublished manuscript, on file with author).

53. See RAWLS, supra note 2, at 118-42.

54. RAWLS, supra note 5, at 225. 
show that the scope of his doctrine of public reason is not excessively narrow. ${ }^{55}$ For example, his "political liberalism" allows people to resort to beliefs drawn from their comprehensive doctrines in a variety of areas that do not touch upon "constitutional essentials" and matters of "basic justice." Even in areas that do touch upon such matters, Rawls's theory allows appeals to comprehensive doctrines subject to the proviso that citizens making such appeals "in due course" show that their position can be justified in terms of public reason. ${ }^{57}$

In Political Liberalism, Rawls offers the following explanation of the demands of public reason:

What public reason asks is that citizens be able to explain their vote to one another in terms of a reasonable balance of public political values, it being understood by everyone that of course the plurality of reasonable comprehensive doctrines held by citizens is thought by them to provide further and often transcendent backing for those values. In each case, which doctrine is affirmed is a matter of conscience for the individual citizen. It is true that the balance of political values a citizens holds must be reasonable, and one that can be seen to be reasonable by other citizens; but not all reasonable balances are the same. The only comprehensive doctrines that run afoul of public reason are those that cannot support a reasonable balance of political values. ${ }^{58}$

Precisely at this point, Rawls inserts a footnote, which, "[a]s an illustration," takes up what he describes as "the troubled question of abortion." Af After stipulating "that we are dealing with the normal case of mature adult women," he asks the reader to "consider the question in terms of these three important political values: the due respect for human life, the ordered reproduction of political society over time, including the family in some form, and finally the equality of women as equal citizens. ${ }^{n 60}$ After acknowledging, parenthetically, that these are not the only important political values, he declares that "any reasonable balance of these three values will give a woman a duly qualified right to decide whether or not to end her pregnancy during the first trimester., 61

How, one may ask, could this bold conclusion be justified without appeal to moral or metaphysical views widely in dispute about the status of embryonic and fetal human beings, or the justice or injustice of choices either to bring

\footnotetext{
55. See id. at lii.

56. Id. at 214-15.

57. See id. at lii.

58. Id. at 243.

59. Id. at 243 n.32.

60. Id.

61. Id.
} 
about their deaths or to perform acts with the foreseeable side effect of bringing about their deaths? Here is Rawls's entire justification: "[A]t this early stage of pregnancy the political value of the equality of women is overriding, and this right is required to give it substance and force." ${ }^{\text {"22 }}$ Why does the value of women's equality override the value of fetal life? Rawls does not say. The absence of argument for this claim is especially remarkable in view of the fact that opponents of abortion contend that the right to life (which, in their view, the unborn share with all other human beings) is fundamental and inviolable and, as such, cannot be "balanced" against other considerations. Rawls goes on to comment that he does not think that the introduction of other political values into the calculation would alter his conclusion, and, indeed, that a reasonable balance of political values might allow a right to abortion even beyond the first trimester, "at least in certain circumstances." ${ }^{63} \mathrm{He}$ explicitly declines to argue the point further, however, stating that his purpose in raising the question of a right to abortion at all is simply "to illustrate the point of the text by saying that any comprehensive doctrine that leads to a balance of political values excluding that duly qualified right in the first trimester is to that extent unreasonable." ${ }^{\text {"4 }}$

Needless to say, Rawls's footnote has elicited vigorous criticism. ${ }^{65}$ As an argument for a right to abortion, it does worse than beg centrally important questions-it ignores them altogether. Moreover, it seems plainly, if silently, to import into the analysis of the question a range of undefended beliefs of precisely the sort that "political liberalism" is supposed to exclude. This smuggling in of controversial moral and metaphysical beliefs is especially egregious in view of the fact that abortion is often put forward as a question that simply cannot be resolved, one way or the other, without introducing such beliefs into the deliberations. ${ }^{66}$ As such, it presents a particular challenge to Rawls's central argument that constitutional essentials and matters of basic justice ought to be resolved by appeal to a purely "political" conception of justice, rather than to general doctrines of justice as parts of reasonable comprehensive views.

In a footnote to the introduction of the new paperback edition of Political Liberalism, ${ }^{67}$ Rawls acknowledges the force of some of these criticisms and offers a brief reply:

62. Id.

63. Id.

64. Id.

65. See Thomas McCarthy, Kantian Constructivism and Reconstructivism: Rawls and Habermas in Dialogue, 105 ETHICS 44, 53 n.16 (1994); see also Michael J. Sandel, Judgemental Toleration, in NATURAL LAW, LIBERALISM AND MORALITY, supra note 37, at 107, 109-10; Sandel, supra note 5, at 1777-78, 1790. 66. See, e.g., Kent GReENawalt, Religious Convictions and Political Choice (1988).

67. RAWLS, supra note 5, at lv-lvi n.31. 
Some have quite naturally read the [original] footnote... as an argument for the right to abortion in the first trimester. I do not intend it to be one. (It does express my opinion, but an opinion is not an argument.) I was in error in leaving it in doubt that the aim of the footnote was only to illustrate and confirm the following statement in the text to which the footnote is attached: "The only comprehensive doctrines that run afoul of public reason are those that cannot support a reasonable balance [or ordering] of political values [on the issue]." To try to explain what I meant, I used three political values (of course, there are more) for the troubled issue of the right to abortion, to which it might seem improbable that political values could apply at all. I believe a more detailed interpretation of those values may, when properly developed at public reason, yield a reasonable argument. I don't say the most reasonable or decisive argument; I don't know what that would be, or even if it exists. ${ }^{\text {s. }}$

At this point, Rawls cites with approval, noting only that he would add several (unspecified) "addenda" to it, Judith Jarvis Thomson's argument for a right to abortion in her then recent article Abortion: Whose Rights' Here is Thomson's summation of her argument:

First, restrictive regulation [of abortion] severely constrains women's liberty. Second, severe constraints on liberty may not be imposed in the name of considerations that the constrained are not unreasonable in rejecting. And third, the many women who reject the claim that the fetus has a right to life from the moment of conception are not unreasonable in doing so. ${ }^{70}$

The affinities of Thomson's approach with Rawlsian political liberalism are obvious. The central pro-life claims are: (1) Human beings in the embryonic and fetal stages, like innocent human beings at all other stages of life, have a right not to be directly (or otherwise unjustly) killed; and (2) like all other human beings, they are entitled to the (equal) protection of the laws against homicide. ${ }^{71}$ Thomson defends the right to aborion, not by claiming that the central pro-life claims are false, but by arguing that their truth or falsity is irrelevant to the political resolution of the question of abortion. "2 What matters is that people are "not unreasonable" in judging the central pro-life claims to be false. Therefore, even those who judge them to be true should

68. Id.

69. The article to which Rawls plainly is refernng is Judith Jarvis Thomson, Aborton, Bostox REV . Summer 1995, at 11.

70. Id. at 15 .

71. See, e.g., Patrick Lee, abortion and Unborn human life (1996), Rober E Juyce. Personhood and the Conception Event, 52 New SCHOLASTICISM 97 (1978); Francas C Wade, Potenholin in the Abortion Discussion, 29 REv. METAPHYsics 239 (1975): Helen Watl. Potentral and the Eurly Human, 22 J. MED. ETHICS 222 (1996).

72. See Thomson, supra note 69 , at 14-15 
refrain from taking political action that would restrict women's freedom based on their judgment. They should join those who consider the central pro-life claims to be false in a sort of Rawlsian overlapping consensus that recognizes a woman's right to abortion.

Here, I submit, we have fully on display all the equivocations, ambiguities, and weaknesses of the Rawlsian criterion of reciprocity, liberal principle of legitimacy, and doctrine of public reason. Immediately after offering the summary of her argument I quoted a moment ago, Thomson, evidently struggling to be generous, says that, "[t]here is of course room for those who accept Catholic doctrine on abortion to declare it in the public forum"; ${ }^{73}$ but, she adds, "those who accept the doctrine ought not say that reason requires us to accept it, for that assertion is false."74 What is Thomson claiming here? Is it that the central pro-life claims should be rejected because they are untrue or, even if true, somehow unreasonable? To establish that, she would have to engage pro-life arguments on the merits and refute them. She makes no serious effort to do so. To have done so would, in any event, have shifted the ground of the argument for a right to abortion from the sphere of Rawlsian "public reason" to an unrestricted debate of a sort that would engage, in violation of Rawlsian scruples, principles connected with competing comprehensive doctrines. ${ }^{75}$

What Thomson seems to mean is that not all "reasonable people" accept pro-life claims, or that the rejection of pro-life claims does not mark a person as "unreasonable." There are, as I suggested earlier, important ways in which assertions like these are true. Contrary to what Thomson supposes, however, nothing follows from the ways in which they are true for the questions whether women have a right to abortion or the unborn have a right not to be aborted. If, in truth, the latter right obtains, and thus the pro-life position is more reasonable than its alternative, then the fact that reasonable people, perhaps without culpability, hold the contrary view in no way vitiates the human right of the unborn not to be killed, or confers upon women a moral right to the more or less unrestricted legal freedom to bring about their deaths. What matters, from the moral point of view, is that basic human rights be identified where they obtain and, to the extent possible, protected.

73. Id. at 15. Thomson does not object "to constraining access to aborion on the ground that the fetus has a right to life [because] this is Catholic, and hence religious doctrine." The "Catholic doctrine" on the subject condemns abortion as homicidal and unjust as a matter of publicly accessible scientific fact and rational (natural law) morality.

74. Id.

75. Moreover, it would undercut the support Thomson's argument supplies to what many find to be the politically attractive (though obviously questionable) idea that people can accept pro-life claims as a basis for being "personally opposed to abortion," yet affirm at the same time support for a legal right to abortion on the ground that the truth of pro-life claims is not relevant to (or, at least, is not determinative of) the question whether women are morally entitled to the legal freedom to abort. 
In the end, Thomson's argument that people are "not unreasonable" in rejecting the pro-life position boils down to an assertion that the argument over the moral status of the human conceptus and early embryo ends in a sort of stalemate: "While I know of no conclusive reason for denying that fertilized eggs have a right to life, I also know of no conclusive reason for asserting that they do have a right to life." ${ }^{\text {76 }}$ Yet one is entitled to this conclusion about the moral status of newly conceived human beings (Thomson's "fertilized eggs") only if one can make an argument sufficient to support it. Such an argument also would have to rebut the arguments put forward to show that the unborn have a right to life even in the earliest stages of their existence. Apart from a few references to Evangelium Vitae, Thomson cites no such arguments at all. There is all the difference in the world between rebutting these arguments and ruling them out in advance on the ground that they implicate deep moral and metaphysical questions in dispute among reasonable people subscribing to competing comprehensive doctrines.

What are the arguments to be rebutted if Thomson is to show that there is nothing unreasonable in rejecting the central pro-life claims? Perhaps these arguments are so tendentious, obscure, or otherwise lacking in rational force that she is justified in ruling them out in advance as legitimate grounds for political action on pro-life principles. In considering the claim that "a human being's life begins at conception," Thomson observes parenthetically, and without further comment or citation, that "[w]e are invited to accept that premise on the ground that the conceptus-a fertilized human egg-contains a biological code that will govern its entire future physical development, and therefore is already a human being." 77 Her suggestion, it seems, is not that the ground adduced for accepting the premise is false, but rather that it is inadequate. It is worth pausing here to consider the implications of the genetic coding and completeness of the human conceptus and early embryo. A human being is conceived when a human sperm containing twenty-three chromosomes fuses with a human egg also containing twenty-three chromosomes (albeit of a different kind) producing a single cell human zygote containing, in the normal case, forty-six chromosomes that are mixed differently from the fortysix chromosomes as found in the mother or father. ${ }^{78}$ Unlike the gametes (that is, the sperm and egg), the zygote is genetically unique and distinct from its parents. Biologically, it is a separate organism. It produces, as the gametes do not, specifically human enzymes and proteins. It possesses, as they do not, the active capacity or potency to develop itself into a human embryo, fetus, infant, child, adolescent, and adult.

Assuming that it is not conceived in vitro, the zygote is, of course, in a

76. Thomson, supra note 69 , at 13

77. Id. at 11 .

78. I will deal with issues raised by the possibility of human cloning later in this Section 
state of dependence on its mother. But independence should not be confused with distinctness. From the beginning, the newly conceived human being directs its own integral organic functioning. It takes in nourishment and converts it to energy. Given an hospitable environment, it will "develop continuously without any biological interruptions, or gaps, throughout the embryonic, fetal, neo-natal, childhood and adulthood stages-until the death of the organism." 79 Thus, according to Dianne Nutwell Irving,

[T] he biological facts demonstrate that at syngamy we have a truly human nature. It is not that he or she will become a human being-he or she already is a human being. . . [A] human zygote or embryo is not a possible human being; nor is he or she potentially a human being; he or she is a human being. ${ }^{80}$

Jed Rubenfeld, in his influential article, On the Legal Status of the Proposition that "Life Begins at Conception", ${ }^{81}$ asserts the contrary. He claims that arguments that life begins at conception are "virtually unintelligible." were true, then Thomson would seem to be justified in effectively ruling such arguments out in advance as reasons for legal restrictions on abortion. The trouble with Rubenfeld's assertion is that he engages no serious scholarly argument in favor of the proposition he claims to be not merely false or inadequate but "virtually unintelligible." Although he cites serious scholarly work in his analyses of claims that "life begins" at various biological marker events in prenatal development such as the point in brain development at which interneural connections within the cerebral cortex make possible higher mental functioning, ${ }^{83}$ he fails to engage a single serious scholarly defense of the proposition whose legal status the title of his article promises to explore. The sole citation he gives for "these arguments" before declaring them to be "virtually unintelligible" is a "well-known antiabortion pamphlet written by Dr. John Willke of the National Right to Life Committee." ${ }^{84}$ To make matters worse, it is unclear whether Rubenfeld has even read this source, since he refers to it only parenthetically as having been discussed by Frances Olsen ( $a$ pro-choice scholar) in a 1989 Harvard Law Review article. ${ }^{85}$

Had Rubenfeld examined the scholarly literature, he could not have imagined, as Thomson did, that the ground of the belief that the lives of new human individuals begin at conception is the bare proposition that

79. Dianne Nutwell Irving, Scientific and Philosoplical Expertise: An Evaluation of the Argunents on "Personhood", LINACRE Q., Feb. 1993, at 18, 23.

80. Id. at 24.

81. Jed Rubenfeld, On the Legal Status of the Proposition that "Life Begins at Conception", 43 STAN.

L. REV. 599 (1991).

82. Id. at 625 .

83. See id. at 617-26.

84. Id. at 625 n.115.

85. See id. (citing Frances Olsen, Unraveling Compromise, 103 HARV. L. REV. 105, 127-28 (1989)). 
"[f]ertilization may be said to represent the moment of genetic completion." This is what Thomson seems to have in mind in referring to the "biological code that will govern its entire future physical development." In response to the argument that life begins at conception, as he imagines it, Rubenfeld says that "[e]very cell in our bodies is genetically complete," supposes that every human cell is a distinct human being with a right to life. This misses the point of the argument that there comes into being at conception, not a mere clump of human cells, but a distinct, unified selfintegrating organism, which develops itself, truly himself or herself, in accord with its own genetic blueprint. The significance of genetic completeness for the status of newly conceived human beings is that no outside genetic material is required to enable the zygote to mature into an embryo, the embryo into a fetus, the fetus into an infant, the infant into a child, the child into an adolescent, the adolescent into an adult. What the zygote needs to function as a distinct self-integrating human organism, a human being, it already possesses.

At no point in embryogenesis does the distinct organism that came into being when it was conceived undergo substantial change or a change of natures. It is human and will remain human. This was the point of Justice Byron White's remark in his dissenting opinion in Thornburgh v. American College of Obstetricians \& Gynecologists ${ }^{88}$ that "there is no nonarbitrary line separating a fetus from a child." ${ }^{189}$ Rubenfeld quotes White's observation and then purports to demolish what he takes to be "[t]he argument based on the gradualness of gestation," by pointing out that, "[n]o nonarbitrary line separates the hues of green and red. Shall we conclude that green is red? That night is day?"'90

The point of the argument is not that development is "gradual," but rather that it is continuous and is the development of a single lasting being. The human zygote that actively develops itself is, as I have pointed out, a genetically complete organism directing its own integral organic functioning. As it matures, in utero and ex utero, it does not "become" a human being, for it is a human being already, albeit an immature human being, the way a newborn infant is an immature human being who will undergo quite dramatic growth and development over time.

These considerations undermine the familiar argument, recited by Rubenfeld, that "[a]n unfertilized ovum also has the potential to develop into a whole human being, but that does not make it a person." a whole human being. It is, rather, a part of another human being (the woman

\footnotetext{
86. Id. at 625 .

87. Id.

88. 476 U.S. 747 (1986) (White, J., dissentung)

89. Id. at 792 (White, J., dissenting).

90. Rubenfeld, supra note 81 , at 625 .

91. Id.
} 
whose ovum it is) with merely the potential to give rise to, in interaction with a part of yet another human being (a man's sperm cell), a new and whole human being. Unlike the zygote, it lacks both genetic distinctness and completeness, as well as the active capacity to develop itself into an adult member of the human species. It is living human cellular material, but, left to itself, however hospitable its environment, it will never become a human being. It will "die" as a human ovum, just as countless skin cells "die" daily as nothing more than skin cells. If successfully fertilized by a human sperm, which, like the ovum (but dramatically unlike the zygote), lacks the active potential to develop into an adult member of the human species, then substantial change-a change of natures-will occur. There will no longer be merely an egg, which was part of the mother, sharing her genetic composition, and a sperm, which was part of the father, sharing his genetic composition; there will be a genetically complete, distinct, unified, self-integrating human organism whose nature differs from that of the gametes-not mere human material, but a human being.

These considerations also make clear that Michael Lockwood, who takes a line on these issues similar to Rubenfeld's, is quite incorrect to say that "we were never week-old embryos, any more than we were sperm or ova." truly makes no sense to say that "l" was once a sperm (or an unfertilized egg) that matured into an adult. Conception was the occasion of substantial change (that is, change from one complete individual entity to another) that brought into being a distinct self-integrating organism with a specifically human nature. By contrast, it makes every bit as much sense to say that I was once a weekold embryo as to say that I was once a week-old infant or a ten-year-old child. It was the new organism created at conception that, without itself undergoing any change of substance, matured into a week-old embryo, a fetus, an infant, a child, an adolescent, and, finally, an adult.

Rubenfeld has another argument: Cloning processes give to nonzygotic cells the potential for development into distinct, self-integrating human beings; thus to recognize the zygote as a human being is to recognize all human cells as human beings, which is absurd. ${ }^{93}$ It is true that a distinct, self-integrating human organism which came into being by a process of cloning would be, like a human organism that comes into being as a monozygotic twin, a human being. That being, no less than human beings conceived by the union of sperm and egg, would possess a human nature and the active potential to mature as a human being. However, even assuming the possibility of cloning human beings from nonzygotic human cells, the nonzygotic cell must be activated by a process which effects substantial change and not mere development or

92. Michael Lockwood, When Does Human Life Begin?, in MORAL DILEMMAS W MODERN MEDICINE 9, 29 (Michael Lockwood ed., 1985).

93. See Rubenfeld, supra note 81 , at $625-26$. 
maturation. Left to itself, apart from an activation process capable of effecting a change of substance or natures, the cell will mature and die as a human cell. not as a human being. ${ }^{94}$ When speaking of the conceptus, Thomson refers to the biological code that will govern "its entire future physical development","95 her syntax points to the relevant entity and reveals the truth that each of us is the human being - that is, the distinct, self-integrating organism-we were as an adolescent, a child, an infant, a fetus, an embryo, and a zygote. Each of us is the "it" who has now experienced the physical development that was in its future when, at conception, it was coded for that development.

I have set forth in some detail the argument that the life of a human being begins at conception, and considered some (though by no means all) of the counterarguments, not to show that the unborn have a right to life (though I believe that they do) or that there is no general right to abortion (though I believe there is not), but to show that the case for the right to life cannot be easily rebutted, nor can the case for a right to abortion-even a "duly qualified" right to abortion "in the first trimester"-be established without engaging the deep moral and metaphysical questions on the basis of which people divide over the question of abortion. If I am correct, Rawlsian "political liberalism" does not offer a way of resolving the social and political conflict surrounding the issue on the basis of principles of justice which can be identified and applied independently of any particular view on these questions. Neither the considerations suggested by Rawls himself nor those advanced by Thomson give those on the pro-life side anything approaching a sufficient reason to surrender in their political struggle for legal protection of the unborn against abortion. They, like their opponents on the pro-choice side, may have good reasons to seek political compromises with their opponents on legislative proposals for the restriction or regulation of abortion, or even to seek a modus vivendi at the constitutional level on the best terms they can obtain. But nothing in the idea of "public reason" gives them grounds to suppose that justice itself requires them to shift from being "politically pro-life" to being merely "personally opposed to abortion, but politically pro-choice."

\section{Homosexual acts, Marriage, and Public Reason}

If abortion is the most explosive issue in our "culture war," questions pertaining to the legal treatment of homosexual acts and relationships are

94. For a valuable examination of the issues Rubenfeld rases, see Michael B Burke, Sorral Essentialism and the Potentiality Principle, 49 REV. METAPHYsics 491. 500-14 (1996), whuch analyzes the beginning of persons through the lens of Aristotelian essentialism. When "Dolly," the sheep bruught into being by cloning, was announced in February of 1997. It was evident that the tume Dolly began was when the nucleus from a somatic cell of Sheep A was fused (electncally) with the denueleated orum of Sheep B.

95. See Thomson, supra note 69, at 11 (emphasis added) 
emerging as the second most incendiary. Assuming that public policy issues regarding sex and marriage go to matters of constitutional essentials and basic justice, Rawlsian political liberalism offers itself as the morally best, or most reasonable, way to resolve political issues concerning homosexual acts and other questions of public policy pertaining to sex and marriage. This way avoids, indeed rules out, appeal to underlying moral and metaphysical questions in dispute among people who give their allegiance to competing comprehensive views. If Rawls is right, reasonable people who reject comprehensive liberalism in favor of views which include more conservative positions on homosexual acts and other questions of sexual morality ought reasonably to be able to join comprehensive liberals in an overlapping consensus on the proper political resolution of these questions.

Disagreements over public policies regarding homosexual conduct and relationships certainly reflect different, incompatible understandings of sexual morality connected to different "comprehensive views." Underlying and informing these different understandings are, once again, profound differences about the nature of human persons and values. Is pleasure intrinsically good and, as such, a noninstrumental reason for action? Or can pleasure, in itself, provide nothing more than subrational motivation? Is the body an aspect of the personal reality of the human being whose body it is? Or is the body a subpersonal part of the human being whose personal reality is the conscious and desiring self which uses the body as an instrument? Is the idea of a true bodily union of persons an illusion? Or are marital acts realizations of precisely such a union? Do nonmarital sexual acts instrumentalize the bodies of those performing them in such a way as to damage their personal integrity? Or are mutually agreeable sexual acts of whatever type morally innocent and even valuable means of sharing pleasure and intimacy and expressing feelings of tenderness and affection?

People's judgments and understandings regarding these and related issues, judgments and understandings that are rarely formal and are usually merely implicit, determine their places on the spectrum ranging from various forms of sexual liberationism to strict forms of conservative sexual morality. ${ }^{96}$ Some proponents of moderate liberalism on questions of sexual morality oppose promiscuity and adultery but maintain that the judgment of traditional natural law theorists and others that fornication and sodomy are intrinsically nonmarital and immoral is misguided. ${ }^{97}$ They believe that nonadulterous and

96. For a defense of sexual liberationism, see DAVID A.J. RICHARDS, SEX, DRUOS, DEATH, AND THB LAW 29-63 (1982); see also Frederick Elliston, In Defense of Promiscuity, in PhILOSOPHICAL PERSPECTIVES ON SEX AND LOVE (Robert M. Stewart ed., 1995). For a classic statement of conservative sexual morality in its strictest form, see St. Augustine, De Bono Coniugali, in ST. Auqustine, TrEatisBs ON MARRIAGE AND OTHER SUBJECTS 21-22 (Roy J. Deferrari ed. \& Charles T. Wilcox et al. trans., 1955).

97. See Stephen Macedo, Homosexuality and the Conservative Mind, 84 GEo. L.J. 261 (1995); see also ANDREW Sullivan, VIRTUAlly Normal: AN ARgument ABout Homosexualtry (1994); Paul Weithman, Natural Law, Morality and Sexual Complementarity, in LAWS AND NATURE (Martha Nussbaum 
nonpromiscuous sexual acts and relationships between loving and devoted partners, whether of opposite sexes or the same sex, can be morally good even outside of marriage. Moreover, they argue that the state should, to be fair to people who are homosexually oriented, make marriage licenses, or at least benefits equivalent to those conferred by legal marriage, available to otherwise eligible same-sex couples.

Together with a coauthor, Gerard V. Bradley, I recently debated issues of marriage and sexual morality, including the question of homosexual acts and relationships, with Stephen Macedo in the pages of the Georgetown Law Journal. ${ }^{98}$ Professor Macedo argues that government has an obligation in justice to its homosexually oriented citizens to issue marriage licenses on a nondiscriminatory basis to same-sex couples. ${ }^{99}$ If I understand Macedo's argument correctly, he defends a conception of marriage as essentially an emotional and, possibly, spiritual union of two loving and devoted persons who may be of opposite sexes or the same sex. The intimacy and overall value of their union is, or may be, enhanced by the parners' cooperation in the performance of mutually agreeable sexual acts. ${ }^{100}$ Professor Bradley and I defend an alternative conception of marriage-one which we believe to be reflected in traditional American and British marriage law, especially in the law governing consummation of marriage. We argue that marriage is a oneflesh (i.e., bodily, as well as emotional, dispositional, and spiritual) union of a male and a female spouse consummated and actualized by sexual acts that are reproductive in type. Such acts consummate and, we maintain, actualize the intrinsic good of marriage whether or not reproduction is desired by the spouses in any particular marital act, or is even possible for them in a particular act or at all. ${ }^{101}$

Macedo is no sexual liberationist. He evidently opposes promiscuity and believes that even consensual sex acts can, in some cases, violate personal integrity or some other moral value. ${ }^{102}$ Nor does he maintain that marriage is a mere social or legal convention that lacks a nature of its own and can therefore legitimately be manipulated to serve the subjective ends of individuals or the state, whatever they happen to be. He shares with people such as Bradley and me the view that not all forms of consensual sexual association ought to be recognized as marriages by the state. ${ }^{103}$ He disagrees with us, however, on questions of the nature of marriage and the role and value of sex within it. ${ }^{104}$

ed., 1996).

\footnotetext{
98. See Macedo, supra note 97; George \& Bradley, supra note t6

99. See Macedo, supra note 97, at 287.

100. See id. at 285-300.

101. See George \& Bradley, supra note 46, at 303-13

102. See Macedo, supra note 97 , at 286-87

103. See id. at 287-89.

104. See id. at $289-93$.
} 
Bradley and I summarize our argument as follows:

(1) Marriage, considered not as a mere legal convention, but, rather, as a two-in-one-flesh communion of persons that is consummated and actualized by sexual acts of the reproductive type, is an intrinsic ... human good; as such, marriage provides a noninstrumental reason for spouses, whether or not they are capable of conceiving children in their acts of genital union, to perform such acts. (2) In choosing to perform nonmarital orgasmic acts, including sodomitical acts-irrespective of whether the persons performing such acts are of the same or opposite sexes (and even if those persons are validly married to each other)-persons necessarily treat their bodies and those of their sexual partners (if any) as means or instruments in ways that damage their personal (and interpersonal) integrity; thus, regard for the basic human good of integrity provides a conclusive moral reason not to engage in sodomitical and other nonmarital sex acts. ${ }^{105}$

Macedo denies these claims. He argues that the organic bodily union of persons we believe to be possible in marital intercourse, whether or not procreation is possible, is illusory. ${ }^{106}$ Thus the reproductive-type acts of spouses cannot possibly have the unitive value and significance we ascribe to them. Marital intercourse cannot be what we claim it is, namely, the biological matrix of the multilevel reality of marriage. The most sex can do for people, beyond making it possible for them to become parents, is to enable them to share pleasure, thus enhancing and enabling them to express in a special way the caring, affectionate, and intimate emotional bond between them. ${ }^{107}$

Macedo also argues that, by confining humanly valuable and morally upright sex to marital intercourse, natural law theorists such as Bradley and I unreasonably exclude sex acts which, though nonmarital (at least in our sense), are nevertheless humanly valuable in their capacity to express and enhance the emotional bonds between lovers. ${ }^{108}$ Moreover, he maintains that we are wrong to deny, as we do, that pleasure is an intrinsic good, or that the instrumentalizing of the body to the end of gaining or sharing pleasurable sensations is intrinsically bad. ${ }^{109}$ Thus he denies that nonmarital sex inevitably damages personal or interpersonal integrity. Bradley and I respond to Macedo's critique of our views by arguing that his understanding of sex and marriage implicates him in a philosophically untenable person-body dualism. ${ }^{110}$ This is most apparent in his denial that human males and females unite biologically when they mate, and in his related understanding of sexual

105. George \& Bradley, supra note 46 , at 301-02 (citations omitted).

106. See Macedo, supra note 97 , at 278-81.

107. See id. at 281-85.

108. See id.

109. See id.

110. See George \& Bradley, supra note 46 , at 311 n.32. 
organs as "equipment" that serves the goods of pleasure and procreation but cannot make possible a truly personal union of spouses as the biological matrix of the multi-level (bodily, emotional, dispositional, spiritual) reality of their marriage. Implicit in these denials, we believe, is the idea that the body is a subpersonal aspect of the human being that serves the conscious and desiring aspect-the true "self"-which inhabits and uses the body. Were Macedo to acknowledge what we believe to be the case, namely, "that the biological reality of human beings is 'part of, not merely an instrument of, their personal reality," 111 then it is difficult to see how he could resist our claim that "the biological union of spouses in marital acts constitutes a truly interpersonal communion," 112 whose value is intrinsic, and not merely instrumental to pleasure or the sharing of pleasure, the expression of tender and affectionate feelings, or any other extrinsic goal.

My point in introducing the debate between Macedo and Bradley and myself is not to try to settle the issues but merely to illustrate that the arguments advanced on both sides plainly implicate a body of assumptions reflective of our respective commitments to very different "comprehensive views." As a result, I suspect, people whose comprehensive view is essentially liberal will find Macedo's argument much more persuasive than ours; those with nonliberal comprehensive views-including traditional-minded Christians, Jews, and other believers-are likely to find our argument more compelling. Still, neither side makes any appeal to principles or propositions that are not publicly available to rational persons. Neither side invokes any form of secret knowledge or revelation. Each side offers people on the other side reasons, which such people may or may not find persuasive, for changing their minds.

My concern for now is not with the truth or falsity of the claims made on either side, or the validity of the arguments advanced on either side to support its claims, but with the relevance of the truth or falsity of these clairns to the resolution of questions of public policy pertaining to sex and marriage and particularly to questions of homosexual acts and relationships. My claim is that political liberalism does not provide a workable alternative to the conflict of comprehensive views on such questions. On the contrary, law and policy in

111. Id. at $301 \mathrm{n} .1$ (quoting John Finnis, Law: Moraliy; and "Sexual Onentatton", 69 NOTKE DaMte L. REV. 1049,1066 (1994)).

112. George \& Bradley, supra note 46 , at $301 \mathrm{n} .1$. We argue that " $|w|$ hen anumals (Ineluding humans) mate, they are united biologically whether or not conception is possible In matung. the male and female pair is, indeed, a 'single reproductive principle.' Reproduction is one acl: yel the act is performed by the mated pair as an organic unit." Id. at 311. As we go on to observe, cutung work by Germain Gnsez, though individual males and females are complete onganisms with respect to other funcuons (ineluding. for example, nutrition and sensation), they are, for reproductive purposes, only potentual halves of a maled paur It is the mated pair that is the complete organism that carnes out the reproducuve function The mated past may, of course, happen to be sterile, but their intercourse, insofar as it is the reproducuve behavior characteristic of the species, unites the copulating male and female as a single organism See ud al $311-13$ (citing nontheological sections of Germain Grisez. The Chnstan Family as Fulfillment of Sacramental Marriage, Paper Delivered to the Sociaty of Christian Ethics Annual Conference (Sept 9. 1995) (unpublished manuscript, on file with author)). 
this area should be shaped in accordance with the truth and will inevitably be shaped by people's ideas about the truth of the moral and metaphysical claims at stake in the debate among advocates of competing comprehensive views.

The case for resolving policy questions in this area on the basis of "political liberalism" is articulated by Macedo himself. Although he contends that the view of marriage and sexual morality that Bradley and I put forward as a ground for public policymaking ought to be rejected as unreasonably narrowing the range of morally valuable sexual conduct and relationships, he argues, in the alternative, that our view constitutes an illegitimate ground for public policy even if it is true and the competing moral view he defends is false. ${ }^{113}$ The upshot of his position for questions of public policy pertaining to homosexual acts and relationships is that justice requires the state to grant marriage licenses to same-sex partners and to recognize their relationship as marital even if, in truth, their sex acts cannot be marital (or morally upright) and their relationship cannot, morally speaking, be a marriage. That is the proposition I am interested in here.

Noting that "[i]t may be, indeed, that Bradley and George and I disagree ... deeply in our understandings of what it is to have reasons for action, about the nature of goods, and perhaps even about the relationship between mind and body," Macedo argues that, "[i]f our disagreements indeed lie in these difficult philosophical quarrels, about which reasonable people have long disagreed, then our differences lie precisely in the territory that John Rawls rightly ... marks off as inappropriate to the fashioning of our basic rights and liberties." ${ }^{\prime 14} \mathrm{He}$ continues:

It is inappropriate to carve up basic rights and principles of justice on the basis of reasons and arguments whose force depends on accepting particular religious convictions. So too it is inappropriate to deny people fundamental aspects of equality based on reasons and arguments whose force can only be appreciated by those who accept difficult to assess claims about the nature and incommensurability of basic goods, the relationship between intrinsic and instrumental value, and the dispute over whether pleasure is a reason for action. ${ }^{115}$

Macedo's Rawlsian argument is certainly appealing on its face. The deep moral and metaphysical questions to which he refers are indeed difficult ones about which reasonable people have long disagreed. Claims on either side of these questions are, as he says, difficult to assess. How could it be right, then, to "deny people fundamental aspects of equality" on the basis of such claims? I certainly do not think it is ever right to deny people fundamental aspects of

113. See Stephen Macedo, Reply to Critics, 84 Geo. L.J. 329, 334-35 (1995).

114. Id.

115. Id. at 335 . 
equality. The question is whether we can identify fundamental aspects of equality pertaining to marriage while prescinding from questions of the nature and value of marriage which, inevitably, implicate deeper moral and metaphysical questions of the sort that Rawls and Macedo wish to rule out of bounds as grounds for public policymaking. Macedo implicitly supposes that we can; I think we cannot.

Macedo's claim about "denying fundamental aspects of equality" can be sustained only if we presuppose the truth of his own comprehensive liberalism. If the nature and value of marriage are, in truth, what Macedo's comprehensive view supposes them to be, then it is indeed a violation of equality to deny marriage licenses and the full legal benefits of marriage to same-sex partners. This violation occurs, however, only because homosexual partners can in fact realize in their sexual acts and relationships the same constitutive value or values (pleasure, intimacy, the expression of tender feelings) that can be realized by heterosexual spouses. No principle of equality is violated, however, if, in truth, homosexual sexual acts and relationships cannot realize the constitutive value or values of marriage-if marriage truly is, as Bradley and I contend, a bodily communion of persons consummated and actualized by sexual acts which are reproductive in type.

On Macedo's view and on mine, marriage is an important value which society and government have an obligation to help make available to people and which the government should not deny to people who are capable of fulfilling its requirements. What follows from this, in my view, is society's obligation to "get it right," that is, to embody in its law and policy a morally sound conception of marriage. This obligation seems to me especially stringent in view of the fact that whatever understanding of marriage is embodied in law and public policy will profoundly shape the public's understanding of the nature and value of marriage, and, thus, affect people's capacities to live out true marriages and participate in their value. This is an area in which moral neutrality strikes me as not only undesirable, but unattainable. The conflict of comprehensive views is unavoidable.

\section{CIVILITY, RECIPROCITY, AND THE CONFLICT OF "COMPREHENSIVE VIEWS"}

The morally charged political disputes of our day, particularly the dispute over abortion, are often compared with the conflict over slavery in the United States in the middle of the nineteenth century. By that point in time, some supporters of slavery were no longer content to defend the "peculiar institution" as a "necessary evil," the toleration of which was required where abolition would allegedly produce disastrous, and therefore morally unacceptable, social and economic consequences. Instead, they contended that slavery was morally good and right, and that the position of their abolitionist 
opponents constituted, not a noble-albeit practically unattainable-moral ideal, but a form of moral and religious fanaticism that threatened the rights of slaveholders. ${ }^{116}$ The conflict of comprehensive views over slavery ultimately defied political compromise and proved to be incompatible with peace and social stability. The matter was finally resolved, but only after a civil war and at a price of nearly three-quarters of a million lives.

Anyone who reflects on the carnage of the American Civil War will applaud Rawls and others for their efforts to come to terms with "the fact of moral pluralism." For those of us who judge, however, that "political liberalism" cannot provide a rational alternative to the conflict of comprehensive views, at least when it comes to morally charged issues such as abortion and homosexuality, the question arises whether it is possible to identify rational standards or ideals of political discourse and action to regulate the conflict. How should people treat those of their fellow citizens with whom they sharply disagree about profoundly important questions of morality, justice, and human rights? What, if anything, do citizens who find themselves in such disagreement owe to each other as a matter of justice in the sphere of political advocacy?

The question of one's obligations toward fellow citizens with whom one disagrees is itself a moral question, indeed, a moral question which implicates, or may implicate, constitutional essentials and matters of basic justice such as questions of freedom of speech and the press, and the right to vote. Deliberation about one's obligations to those who advocate policies which one believes to be seriously unjust will be informed by one's general or "comprehensive" views about justice. There is, I believe, no reason to suppose that people can or should attempt to prescind from their "comprehensive views" in determining their obligations to those with whom they find themselves in morally charged political conflict.

However, a certain substantial "overlapping consensus" in fact exists between a great many thoughtful people on both sides of contemporary debates over issues such as abortion and homosexuality regarding people's obligations to their political opponents. Most fundamentally, perhaps, there is a significant level of moral as well as pragmatic agreement about the need to respect basic freedoms of speech, press, and religion, and the right to vote. Of course, there is a measure of disagreement at the margins about the scope of some of these rights. Differences break out, for example, over the free speech rights of advertisers of abortion services, on the one hand, and of protesters and sidewalk counselors at abortion clinics, on the other. ${ }^{117}$ Nevertheless, most

116. For an illuminating account of the arguments over slavery in this period, see generally WILLIAM LEe Miller, ARguiNg ABOUT Slavery 36 (1996), which observes that "[t]he use of the word 'fanatic' to describe the [antislavery] petitioners became so constant as to verge on the automatic."

117. See, e.g., Schenck v. Pro-Choice Network, 65 U.S.L.W. 4109 (U.S. Feb. 19. 1997); Madsen v. Women's Health Ctr., Inc., 512 U.S. 753 (1994). 
pro-life and pro-choice advocates respect the rights of their opponents to express and publicize their views and arguments.

Furthermore, it seems at least possible for citizens who differ fundamentally over certain basic moral questions to share a "deliberative" conception of democracy that includes the mutually recognized obligations of citizens to treat those with whom they disagree with civility and respect. In a valuable new book on the subject of moral conflict in the context of democratic politics, Amy Gutmann and Dennis Thompson have remarked that the "core idea" of "deliberative democracy" is that "when citizens or their representatives disagree morally, they should continue to reason together to reach mutually acceptable decisions." 118 Gutmann and Thompson do not suppose that these efforts will always be successful, or that, somehow, by reasoning together, differences of "comprehensive views" can be made to melt away. Nor do they imagine that regulative principles of debate and discussion-such as the principles of "reciprocity," "publicity," and "accountability" which figure centrally in what they call "the constitution" of deliberative democracy - will dictate substantive policies, liberal or otherwise, on issues such as abortion. ${ }^{119}$ Their claim, rather, is that "reciprocity," which they consider to be deliberative democracy's "first principle,"120 demands that people recognize that others who come down on what they judge to be the wrong side of a disputed moral question may nevertheless be reasonable and honest people who deserve, therefore, to be reasoned with and treated with respect. Yet reasoning with people and treating them with respect does not entail tolerating what one judges to be grave injustices so as not to offend those who judge otherwise. Nor does it mean that one ought not to oppose injustices resolutely and forcefully in one's advocacy and action. Nor does it mean that one may not protest against injustices or even practice civil disobedience to prevent them. ${ }^{121}$ It does mean, however, that one has certain obligations to one's opponents, obligations that are not mere matters of politeness.

Deliberative democracy is more than a matter of competing to assemble majorities for positions that one believes to be in one's interest or even morally right. In a deliberative democracy, citizens understand and accept the duty to justify their positions to their fellow citizens who disagree with them. In this respect, it includes something like an ideal of "public reason," but not one so narrow as to exclude, as Rawls's ideal of public reason purports to do,

118. Amy GUtmann \& DenNis Thompson, Democracy and Disagreement I (1996)

119. On the content and significance of these regulatuve prnasiples and other pnneiples comprising the constitution of deliberative democracy, see $i d$.

120. Id. at 2.

121. For a succinct and, in my view, sound treatment of the morality of civl disobedtence, see Fowis ET AL., supra note 46, at 354-57. On the vexed question of when violence may be used to combat injustices, see $i d$. at $308-18$. 
reasonable alternatives to liberal positions on such issues as abortion and homosexuality. In other words, it does not "load the dice" in favor of substantive liberal policies.

A sound principle of public reason for a deliberative democracy would indeed require citizens and policymakers to justify their political advocacy and action by appeal to principles of justice and other moral principles accessible to their fellow citizens by virtue of their "common human reason." It would, however, exclude no reasonable view in advance of its dialectical consideration "on the merits" in public debate. Nor would it exclude religious views as such. What it would exclude, rather, as grounds of public policymaking generally, are appeals to sheer authority (religious or otherwise) or to "secret knowledge," or the putative truths revealed only to an elite (or the elect) and not available, in principle, to rational persons as such. ${ }^{122} \mathrm{~A}$ sound principle of public reason would, in short, be very wide. Its goal would be the "perfectionist" one of settling law and public policy in accordance with what is true as a matter of justice, human rights, and political morality generally.

I have indicated elsewhere my own broad agreement with the conception of deliberative democracy advanced by Gutmann and Thompson, albeit indicating certain areas in which I would be inclined to amend, and, more importantly, extend their conception of "reciprocity." 23 Inasmuch as Gutmann and Thompson plainly are committed to a broadly liberal comprehensive view, and I am not, this agreement of moral principle about regulative ideals which should govern morally charged political conflict reflects an "overlapping consensus" that goes beyond the mutual recognition of basic political rights. A consensus of this sort holds out the promise that reasonable people of goodwill who have arrived at sharply different conclusions about basic questions of morality, justice, and human rights may nevertheless recognize moral reasons to conduct their political disputes with civility and enjoy the common goods of peace and social stability that are the fruit of such civility.

122. My idea of a sound conception of public reason is similar to the one defended by Michacl Sandel, who rejects Rawls's restrictions on public reason in favor of "a more expansive conception, a public reason of moral and religious engagement." Michael Sandel, in Symposium, Political Liberalism: Religion and Public Reason, 3 RELIGION \& VALUES IN PUB. LIFE 1, 3 (1995). Also noteworthy are Sandel's comments regarding religious contributions to moral reasoning about abortion. See id. at 9; see also Sandel, supra notc 5 , at 1789-94.

123. See George, supra note 48. 